\title{
GMR
}

\section{Genetic divergence among corn hybrids and combining ability for agronomic and bromatological traits of silage}

\author{
E. Gralak ${ }^{1}$, M.V. Faria ${ }^{1}$, A.S.T. Figueiredo ${ }^{2}$, D.A. Rizzardi ${ }^{3}$, M. Neumann ${ }^{4}$, \\ M.C. Mendes ${ }^{1}$, C.A. Scapim ${ }^{3}$ and S. Galbeiro ${ }^{5}$ \\ ${ }^{1}$ Departamento de Agronomia, Campus Universitário Cedeteg, \\ Universidade Estadual do Centro-Oeste, Guarapuava, PR, Brasil \\ ${ }^{2}$ Departamento de Pesquisa em Melhoramento de Hortaliças, \\ Estação de Pesquisa e Desenvolvimento Sakata, Bragança Paulista, SP, Brasil \\ ${ }^{3}$ Departamento de Agronomia, Campus Maringá, \\ Universidade Estadual de Maringá, Maringá, PR, Brasil \\ ${ }^{4}$ Departamento de Medicina Veterinária, Campus Universitário Cedeteg, \\ Universidade Estadual do Centro-Oeste, Guarapuava, PR, Brasil \\ ${ }^{5}$ Departamento de Medicina Veterinária, Campus Universitário Londrina, \\ Universidade Estadual de Londrina, Londrina, PR, Brasil \\ Corresponding author: A.S.T. Figueiredo \\ E-mail: alex.figueiredo@sakata.com.br / alexstfigueiredo@gmail.com
}

Genet. Mol. Res. 16 (2): gmr16029643

Received February 8, 2017

Accepted April 3, 2017

Published May 25, 2017

DOI http://dx.doi.org/10.4238/gmr16029643

Copyright $\left({ }^{\circ} 2017\right.$ The Authors. This is an open-access article distributed under the terms of the Creative Commons Attribution ShareAlike (CC BY-SA) 4.0 License.

\begin{abstract}
We assessed the impact of genetic divergence and the ability to combine corn hybrids used for the production of silage on the agronomic and bromatological traits of silage quality. We evaluated 18 corn hybrids used as genitors in a circulant diallel scheme in which each genitor hybrid participated in 9 hybrid combinations, and evaluated 100 treatments [18 genitor hybrids, 81 diallelic hybrids, and a commercial check hybrid (DKB330)] in a triple lattice $10 \times 10$ experimental design in two environments in Brazil. Genetic variability
\end{abstract}

Genetics and Molecular Research 16 (2): gmr16029643 
was adequate among the corn silage hybrids, and we can recommend the use of genitors $2 \mathrm{~B} 688$ and $\mathrm{P} 30 \mathrm{~B} 39$ for the formation of a base population for intrapopulational breeding. The P30P34 hybrid is the best for intrapopulational breeding when aiming for silage with high protein content, low fiber content, and higher in vitro digestibility. Interpopulational breeding directed at improving silage digestibility can use a combination of genitors P30P34 and AS1572, but AS1572 and P30K64 are the most recommended. Hybrids 2B688, P30P34, and SG6015 are considered the most genetically distant of the others hybrids, and have desirable combining potential; therefore, they are important genitors for the formation of new segregated populations for improving corn silage.

Key words: Zea mays; Partial diallel; Base population; Genetic distance

\section{INTRODUCTION}

Corn (Zea mays) is the most popular species for silage production (de Oliveira et al., 2011) because it is easy to cultivate, has a high dry mass yield, is digestible, palatable to animals, and has high nutritional value (Neumann et al., 2009). In Brazil, as in the rest of the world, nearly $80 \%$ of the produced corn is directly or indirectly used for animal consumption, which demonstrates the importance of this crop to the sustainability of the livestock system (Marcondes et al., 2015). The first and one of the most important stages of a corn breeding program is the formation of a base population, because the sources of extraction of elite inbred lines originate new hybrids (Hallauer et al., 2010). Corn breeders routinely use germplasm with a narrow genetic base to form the base population because such an approach has several advantages: a high frequency of favorable alleles; pest and disease resistance; and, most importantly, high adaptability to different soil and climate conditions (Oliboni et al., 2013; Senhorinho et al., 2015).

Currently, 162 corn hybrids are recommended for the production of grain and wholeplant silage in Brazil's corn market. These hybrids are important sources of genetic variability for the base population of corn genetic breeding programs, even when the major aim is to produce silage (Mendes et al., 2015). However, the selection of the best hybrids must be supported by genetic parameters such as genetic divergence among genitors, combining ability, and favorable allele frequency (Mendes et al., 2015, de Souza Neto et al., 2015).

Combining ability, as estimated by diallel crossing, is widely used in corn breeding programs because it provides information about heterosis and the prevailing genetic effect on the control of traits, and helps in the selection of the best improvement strategies and the best genitors for the base population (Miranda Filho and Gorgulho, 2001). However, when the number of genitors is fairly large, some types of diallel cross are impossible owing to the high number of crosses and the difficulty in evaluating hybrid combinations in experiments with repetitions in different environments (Cruz et al., 2012). In such cases, the alternative is the circulant diallel in which a sample of possible crosses among $p$ genitors is taken. In a circulant diallel, $p$ progenitors represented in $s$ hybrid combinations are evaluated (Kempthorne and Curnow, 1961).

In Brazil, there are several genetic programs for breeding corn specifically for silage,

Genetics and Molecular Research 16 (2): gmr16029643 
and the preferred hybrids are usually those with the highest grain yields. Therefore, there is a need to improve the quality of corn silage produced in Brazil. Besides grain yield, it is important to consider other hybrid qualities such as nutritional value, which is partly related to the digestibility of the dry matter, and the proportion of fibrous plant material (almost $60 \%$ of the final volume of the silage).

In this study, we aimed to evaluate genetic divergence and combinatorial ability in 18 commercial corn hybrids that are recommended for silage production. We considered the agronomic and bromatological aspects of silage quality with the aim of selecting a germplasm for the synthesis of a new base population for the production of silage with high nutritional value.

\section{MATERIAL AND METHODS}

\section{Treatments, trials, and environmental conditions}

We conducted two experiments in the south-central region of the State of Paraná (PR), Brazil, during 2010/2011. The first trial was conducted at the experimental area of the Campus CEDETEG of the State University of Midwest in Guarapuava, PR, and the second experiment was carried out at Touros Farm in the city of Candói, PR.

We used 18 commercial corn hybrids as genitors $(p=18)$ in a circulant diallel scheme, in which each genitor participated in nine hybrid combinations $(s=9)$. Altogether, we evaluated 100 treatments in Guarapuava and Candói (18 hybrid genitors; 81 hybrid combinations of the genitors; and a commercial hybrid called DKB330) using a triple lattice $10 \times 10$ experimental design (Table 1). The main traits of the hybrids and genitors, and the experimental conditions applied to the partial diallels and DKB330, are given in Table 1.

\begin{tabular}{|c|c|c|c|c|c|c|c|c|}
\hline Hybrid & Company & Genetic base $^{\mathrm{a}}$ & Grain type & Grain color & Cycle & Segment & Ear height & Plant height \\
\hline P30R50 & Pionner & SH & Semi flint & Yellow & Earliness & Grain & 1.25 & 2.80 \\
\hline P30F53 & Pionner & SH & Semi flint & Orange & Earliness & Grain & 1.15 & 2.70 \\
\hline P30B39 & Pionner & $\mathrm{mSH}$ & Semi flint & Orange & Earliness & Grain/Whole plant & 1.35 & 3.00 \\
\hline P30K64 & Pionner & SH & Semi flint & Orange & Earliness & Grain & 1.50 & 3.20 \\
\hline P30P34 & Pionner & $\mathrm{mSH}$ & Semi flint & Orange & Earliness & Grain/Whole plant & 1.30 & 2.40 \\
\hline AG8021 & Agroceres & $\mathrm{SH}$ & Semi dent & Orange & Earliness & Grain & 1.30 & 2.30 \\
\hline AG5011 & Agroceres & TH & Dent & Yellow & Earliness & Grain/Whole plant & 1.30 & 2.30 \\
\hline Garra & Syngenta & TH & Flint & Orange & \begin{tabular}{|l|} 
Earliness \\
\end{tabular} & Grain & 1.30 & 2.23 \\
\hline Attack & Syngenta & $\mathrm{mSH}$ & Flint & Orange & \begin{tabular}{|l|} 
Earliness \\
\end{tabular} & Grain/Whole plant & 1.33 & 2.19 \\
\hline CD304 & Coodetec & TH & Flint & Yellow & S. earliness & Grain/Whole plant & 1.10 & 2.21 \\
\hline CD308 & Coodetec & DH & Semi flint & Orange & Earliness & Grain/Whole plant & 1.09 & 1.94 \\
\hline SG6010 & \begin{tabular}{|l|} 
SGuerra \\
\end{tabular} & SH & Dent & Yellow & Earliness & Grain/Whole plant & 1.20 & 2.30 \\
\hline SG6015 & SGuerra & $\mathrm{SH}$ & Dent & Yellow & Earliness & Grain/Whole plant & 1.30 & 2.50 \\
\hline 2B688 & Dow Agro & TH & Semi Flint & Orange & Earliness & Grain/Whole plant & 1.15 & 2.10 \\
\hline GNZ2004 & Geneze & $\mathrm{SH}$ & Semi dent & Orange & Earliness & Grain/Whole plant & 1.20 & 2.50 \\
\hline AS1560 & Agroeste & SH & Semi dent & Yellow & Earliness & Grain/Whole plant & 1.50 & 2.75 \\
\hline AS1551 & Agroeste & SH & Semi flint & Yellow & S. earliness & Grain/Whole plant & 1.23 & 2.28 \\
\hline AS1572 & Agroeste & SH & Semi flint & Yellow & S. earliness & Grain/Whole plant & 1.25 & 2.45 \\
\hline DKB330 & Dekalb & $\mathrm{SH}$ & Flint & Orange & Earliness & Grain/Whole plant & 1.30 & 2.10 \\
\hline \multicolumn{9}{|c|}{ Environment } \\
\hline \multicolumn{2}{|l|}{ Location } & \multicolumn{2}{|c|}{ Altitude $(\mathrm{m})$} & Latitude & \multicolumn{2}{|c|}{ Longitude } & \multicolumn{2}{|c|}{ cumulated rainfall $(\mathrm{mm})$} \\
\hline \multicolumn{2}{|l|}{ Guarapuava } & \multicolumn{2}{|l|}{1120} & $25^{\circ} 23^{\prime} 2^{\prime \prime S}$ & \multirow{2}{*}{\multicolumn{2}{|c|}{$\begin{array}{l}51^{\circ} 29^{\prime} 43^{\prime \prime} \mathrm{W} \\
52^{\circ} 01^{\prime} 55^{\prime \prime} \mathrm{W}\end{array}$}} & \multicolumn{2}{|l|}{1100} \\
\hline \multicolumn{2}{|l|}{ Candói } & \multicolumn{2}{|l|}{916} & $25^{\circ} 37^{\prime} 46^{\prime \prime S}$ & & & \multicolumn{2}{|l|}{980} \\
\hline
\end{tabular}

${ }^{\mathrm{a}} \mathrm{SH}=$ single hybrid; $\mathrm{mSH}=$ modified single hybrid; $\mathrm{TH}=$ triple hybrid; $\mathrm{DH}=$ double hybrid.

Genetics and Molecular Research 16 (2): gmr16029643 
Both experiments were performed under a no-till system. Plots comprised three contiguous sowing rows with $0.8 \mathrm{~m}$ between each row, with a density of five useful plants per linear meter.

Based on the chemical analysis of the soil and the expectation of high production of green mass ( $>75 \mathrm{t} / \mathrm{ha}$ ), we applied $328 \mathrm{~kg} / \mathrm{ha}$ of NPK 08-20-15 as base fertilizer. We applied two lots of nitrogen fertilization to the growing area, i.e., $90 \mathrm{~kg} / \mathrm{ha}$ of nitrogen in the form of urea $(45 \% \mathrm{~N})$ in two applications to the corn development stadia $\mathrm{V}_{4}-\mathrm{V}_{5}$ and $\mathrm{V}_{8}-\mathrm{V}_{9}$.

\section{Assessment of agronomical and bromatological silage quality traits}

We evaluated the following agronomical traits: grain yield (GY: total mass of grain in $\mathrm{t} / \mathrm{ha}$ at $13 \%$ of humidity); prolificacy (PRO: average number of corn cobs per plant); stem diameter (SD: diameter from the second internode above the soil level measured using a digital pachymeter); female flowering (FF: number of days between the emergence and flowering of more than $50 \%$ of the plants in the central line); plant height (PH: height, in meters, from the soil to the flag leaf insertion); ear insertion height (EH: height, in meters, from the soil to the main ear insertion); leaf width (LW: width, in centimeters, of the leaf associated with the main ear); leaf length (LL: length, in centimeters, of the leaf associated with the main cob); number of leaves above the main ear (NLA); internode length (IL: length, in centimeters, of the internode insertion on the main ear); number of leaves below the main ear (NLB); tassel main stem length (TMSL: length, in centimeters, of the tassel main stem); tassel secondary stem length (TSSL: length, in centimeters, of the tassel secondary stem); and tassel stem number (TSN: average number of tassel stems).

Forty days after female flowering when the grains showed nearly one-quarter of the milk line, plants from the central line of the Guarapuava trial plot were manually cut at $0.20 \mathrm{~m}$ above the soil to determine the green mass yield of the forage at the point of silage (GMY: t/ha). Six plants were chopped into $2.0-\mathrm{cm}$ pieces. We prepared silage out of a 2.5 $\mathrm{kg}$ homogeneous sample in experimental hermetically sealed polyvinyl chloride (PVC) silos. After 150 days, we opened the silos and dried $0.3-\mathrm{kg}$ samples from the silo's central mass in forced ventilation ovens at $55^{\circ} \mathrm{C}$ until we obtained a constant weight to determine the mass of the air-dried samples. We ground the samples in a knife mill with $1.0-\mathrm{mm}$ sieves to determine the final dry matter at $105^{\circ} \mathrm{C}$ for bromatological analysis, and obtained the final dry matter yield (DMY: t/ha) based on the definitive dry matter and green mass yield.

We evaluated each sample in duplicate at the Animal Nutrition Laboratory of UNICENTRO for the following bromatological silage quality traits: crude protein content [CP: \% of dry matter (DM)], as described by Silva and de Queiroz (2012); and acid detergentinsoluble fiber (ADIF) content and neutral detergent-insoluble fiber (NDIF) content, as described by Van Soest et al. (1991). We determined in vitro dry matter digestibility (IVDMD) at the Feed and Nutrition Lab of UEM, according to the method described by Tilley and Terry (1963) adapted to the use of an artificial rumen developed by Ankon ${ }^{\circledR}$.

\section{Statistical analysis and estimated parameters}

Initially, the data from the experiments conducted in Guarapuava and Candói were subjected to individual analysis of variance according to the lattice design, opting for intrablock analysis with interblock information recovery to obtain adjusted means using

Genetics and Molecular Research 16 (2): gmr16029643 
lattice-effective error. After individual variances for GY, PRO, SD, FF, PH, and EH had been verified, we were presented with the possibility of performing joint analysis using Hartley's test, which evaluates homoscedasticity with average squares of effective error of variance analysis.

To estimate genetic distance between the genitor hybrids in the circulant diallel scheme, we conducted a multicollinearity diagnosis based on the phenotypic correlation estimative among the traits analyzed in each environment. We aimed to select variables that allowed a final weak multicollinearity $(\mathrm{NC}<100)$, and avoided negative grouping analyses. We selected 13 quantitative traits to study genetic divergence in Guarapuava (GY, GMY, DMY, SD, FF, CP, ADIF, IVDMD, LW, LL, NLA, IL, and TMSL) and 14 traits to study divergence in Candói (GY, PRO, SD, FF, PH, EH, LW, LL, NLA, NLB, IL, TSL, TSSL, and NLB). Using the adjusted means of these variables, we estimated genetic divergence among the 18 corn hybrids used in the circulant diallel scheme through standardized averages of Euclidean distance by phenotypic standard deviation of each trait. We grouped the 18 hybrids using Tocher's agglomerative method with maximum distance between minimum limits of intergroup distances as the criterion to form the groups.

We obtained combining ability estimates according to Kempthorne and Curnow (1961) by considering $p=18$ genitors and $s=9$ crosses of each genitor, where $s<p-1$ and $s$ $\geq 2$ for a diallel that included $\mathrm{F}_{1}$ 's and genitors; $p s / 2=81$ : ratio relative to the total number of hybrid combinations; and $\mathrm{k}=(p+1-s) / 2=5$ : ratio relative to a whole number that defines the inferior and superior limit of the diallel.

We estimated classificatory Spearman correlation coefficients $(\mathrm{P}<0.05)$ to verify ranking coincidence among genetic distances of genitor hybrids with specific combinatorial abilities and the mean of the respective hybrid combinations for agronomic and bromatological characters of silage quality.

We used the Genes computer software package (Cruz, 2013) to perform individual and joint analyses of variance, Pearson phenotypic correlation analysis, genetic divergence analysis, Tocher's agglomerative method, and individual and joint diallel analyses. We obtained Spearman's classificatory correlation coefficients using the "spearman" statistical package associated with the R statistical platform.

\section{RESULTS AND DISCUSSION}

\section{Individual and join analyses of variance and heritability}

Table 2 summarizes the results for the individual and joint analyses of variance, and presents the genetic parameters estimated for the agronomic and bromatological traits of corn silage quality. The lattice design was efficient $(\geq 100 \%)$ for most of the traits analyzed, except NDIF and FF from the Guarapuava trial and EH from the Candói trial (Table 2). These data indicate the correct choice of design of treatments in the field.

There was significant genetic variability between the different treatments for all bromatological traits of the silage assessment in the Guarapuava trial, and for agronomic traits observed in the Guarapuava and Candói trails (Table 2). Such results show that commercial corn germplasm is an important source of genetic variability for corn silage enhancement programs, and they provide important alleles to improve various traits related to the bromatological quality of silage.

Genetics and Molecular Research 16 (2): gmr16029643 
Table 2. Summary of individual and joint variance analyses of square triple lattice design with 100 treatments for agronomic and bromatological quality traits of corn silage.

\begin{tabular}{|c|c|c|c|c|c|c|c|}
\hline \multicolumn{8}{|l|}{ Environment I - Guarapuava, PR } \\
\hline \multirow[t]{2}{*}{ Source of variation } & \multirow[t]{2}{*}{ d.f. } & \multicolumn{6}{|c|}{ Square of mean } \\
\hline & & GMY $(\mathrm{t} / \mathrm{ha})^{2}$ & DMY $(\mathrm{t} / \mathrm{ha})^{2}$ & $\mathrm{CP}(\% \mathrm{~ms})^{2}$ & ADIF $(\% \mathrm{~ms})^{2}$ & NDIF $(\% \mathrm{~ms})^{2}$ & IVDMD $(\% \mathrm{~ms})^{2}$ \\
\hline Replication & 2 & 81.04 & 1.64 & 0.0658 & 1.077 & 2.47 & 1.29 \\
\hline Block/Replication (adjustment) & 27 & 87.57 & 4.63 & 0.1312 & 1.829 & 2.12 & 3.34 \\
\hline Treatment (adjustment) & 99 & $76.98^{*}$ & $8.64^{*}$ & $0.3340^{*}$ & $10.95^{*}$ & $40.23 *$ & $21.69^{*}$ \\
\hline Effective error & 171 & 30.95 & 3.27 & 0.1292 & 1.629 & 4.078 & 3.045 \\
\hline Mean & - & 68.68 & 18.38 & 6.85 & 32.11 & 51.40 & 73.78 \\
\hline Lattice efficiency & - & 117.64 & 102.01 & 100.01 & 100.23 & 93.45 & 100.15 \\
\hline Heritability & - & 0.59 & 0.60 & 0.61 & 0.85 & 0.89 & 0.85 \\
\hline Variation coefficient & - & 8.10 & 9.84 & 5.24 & 3.97 & 3.92 & 3.72 \\
\hline Maximum & - & 82.32 & 22.66 & 7.85 & 36.73 & 64.02 & 79.83 \\
\hline Minimum & - & 54.04 & 14.30 & 6.08 & 28.36 & 44.32 & 54.07 \\
\hline Amplitude & - & 28.28 & 8.36 & 1.76 & 8.37 & 19.70 & 24.87 \\
\hline \multicolumn{8}{|l|}{ Joint analysis } \\
\hline & & GY $(\mathrm{t} / \mathrm{ha})^{2}$ & PRO (ears/plant) ${ }^{2}$ & $\mathrm{SD}(\mathrm{cm})^{2}$ & FF (days) ${ }^{2}$ & $\mathrm{PH}(\mathrm{m})^{2}$ & $\mathrm{EH}(\mathrm{m})^{2}$ \\
\hline Environment & 1 & $289.25^{*}$ & $0.028^{*}$ & $0.197^{\text {ns }}$ & $1.54^{*}$ & $0.5122 *$ & $2.74^{*}$ \\
\hline Treatment (adjustment) & 99 & $4.72 *$ & $0.0091^{*}$ & $0.1551 *$ & $17.59^{*}$ & $0.0758^{*}$ & $0.0483^{*}$ \\
\hline Treatment $\mathrm{x}$ environment (adjustment) & 99 & $1.25^{*}$ & $0.0034^{\mathrm{ns}}$ & $0.131^{\mathrm{ns}}$ & $6.89^{*}$ & $0.0132 *$ & $0.014 *$ \\
\hline Effective error mean & 342 & 0.77 & 0.0026 & 0.1035 & 2.97 & 0.005 & 0.0054 \\
\hline Genetic parameter & Environment & GY (t/ha) & PRO (ears/plant) ${ }^{2}$ & $\mathrm{SD}(\mathrm{cm})$ & FF (days) & $\mathrm{PH}(\mathrm{m})$ & $\mathrm{EH}(\mathrm{m})$ \\
\hline \multirow[t]{2}{*}{ Lattice efficiency (\%) } & Guarapuava & 114.41 & 104.82 & 103.07 & 90.90 & 116.80 & 104.65 \\
\hline & Candói & 115.75 & 100.81 & 100 & 100 & 100.36 & 94.68 \\
\hline \multirow[t]{2}{*}{ Heritability (\%) } & Guarapuava & 73.53 & 60.89 & 5.73 & 99.91 & 88.40 & 85.10 \\
\hline & Candói & 74.41 & 50.71 & 61.78 & 61.47 & 89.17 & 80.16 \\
\hline \multirow{2}{*}{ Variation coefficient (\%) } & Guarapuava & 8.10 & 5.41 & 24.03 & 2.45 & 2.85 & 4.63 \\
\hline & Candói & 8.14 & 4.16 & 12.53 & 3.61 & 3.08 & 6.15 \\
\hline \multirow[t]{2}{*}{ Mean } & Guarapuava & 10.10 & 1.06 & 1.68 & 70.73 & 2.40 & 1.43 \\
\hline & Candói & 11.49 & 1.05 & 1.64 & 67.51 & 2.34 & 1.30 \\
\hline
\end{tabular}

*Significant and $\mathrm{ns}=$ not significant according to the $\mathrm{F}$ test $(\mathrm{P}<0.05)$; GMY: green mass yield $(\mathrm{t} / \mathrm{ha})$; DMY $=$ dry matter yield ( $\mathrm{t} / \mathrm{ha}) ; \mathrm{CP}=$ crude protein ( $\%$ of dry matter); $\mathrm{ADIF}=$ acid detergent-insoluble fiber ( $\%$ of dry matter); $\mathrm{NDIF}=$ neutral detergent-insoluble fiber ( $\%$ of dry matter); IVDMD: in vitro dry matter digestibility $(\%$ of dry matter); $\mathrm{GY}=$ grain yield (t/ha); $\mathrm{PRO}=$ prolificacy (number of ears $/$ plant); $\mathrm{SD}=$ stem diameter $(\mathrm{cm}) ; \mathrm{FF}=$ female flowering (days); $\mathrm{PH}=$ plant height $(\mathrm{m}) ; \mathrm{EH}=$ ear insertion height $(\mathrm{m})$.

The source of variation treatments vs. location was significant $(\mathrm{P}<0.05)$ for GY, FF, $\mathrm{PH}$, and EH (Table 2), indicating that the phenotypic averages of the different genotypes were modified as a result of variations in soil and climate conditions where they were analyzed, as a result of specific interactions between genotypes and environments. Many studies have indicated interactions between corn genotypes and the environment for several important traits such as grain yield and bromatological quality of silage (Gralak et al., 2014; de Souza Neto et al., 2015; Marcondes et al., 2015; Mendes et al., 2015; Marcondes et al., 2016).

The source of local variation was significant $(\mathrm{P}<0.05)$ for most of the analyzed traits, which indicates that although the environments were similar, they were capable of causing different behavior in the corn hybrids (Tables 1 and 2). Such results corroborate those of Pfann et al. (2009), Oliboni et al. (2013), and Gralak et al. (2014), who evaluated different corn genotypes in different locations in the South Central region of Paraná and concluded that environments that are fairly similar may cause significant modifications in corn hybrid performance.

Broad sense heritability $\left(\mathrm{h}_{\mathrm{a}}^{2}\right)$ indicates to what extent phenotypic variability is caused by genetic or inheritable causes, and is of major importance for plant improvers because it has a direct impact on the genetic gains obtained by selection (Hallauer et al., 2010). Thus, the higher the heritability estimate, the closer the association between the phenotype and genotype, and the smaller the environmental influence on trait expression. The broad sense heritability estimates $\left(\mathrm{h}_{\mathrm{a}}^{2}\right)$ for GMY, DMY, and SD were less than $61 \%$, which indicates that 
such characteristics are possibly polygenic in nature and are induced by environmental effects (Table 2). However, the $\mathrm{h}_{\mathrm{a}}^{2}$ values for traits related to the bromatological quality of the silage were high, varying from $85 \%$ for ADIF and IVDMD to $89 \%$ for NDIF (Table 2). Such results indicate that effective selection may depend to a small extent on environmental influences, but the observed phenotypic variability is chiefly caused by genetics.

The results from studies that have investigated the heritability of bromatological traits of corn silage are highly variable. Gomes et al. (2004) reported in situ matter degradation, $\mathrm{a}_{\mathrm{a}}{ }^{2}$ of $65.99 \%$, and an NDIF of $80.37 \%$, and concluded that heritability is the best genetic parameter for the potential improvement of a trait. Krakowsky et al. (2006) worked with populations from elite lines of corn and reported $\mathrm{h}_{\mathrm{a}}^{2}$ values of $93 \%$ for ADIF, $94 \%$ for NDIF, and $67 \%$ for lignin. Ertiro et al. (2013) reported high $\mathrm{h}_{\mathrm{a}}^{2}$ values for in vitro dry matter digestibility $(80 \%)$, and ADIF and NDIF (81\%), and the results were close to those from our current study. Marcondes et al. (2016) evaluated top-crosses of hybrids of partially inbred lines with elite lines and observed heritability values for ADIF and NDIF of $58 \%$ and $75 \%$, respectively. They concluded that satisfactory genetic gains may be achieved by the selection of individual plants with lower fiber content.

Silage digestibility is the most important aspect of nutritional quality because it is directly associated with an animal's ability to exploit food (Argillier et al., 1998; Argillier et al., 2000). In the present study, the IVDMD of the silage varied from 54.07 to $79.83 \%$ with $a h_{a}{ }^{2}$ of $85 \%$ (Table 2). This enables genotypes with better silage digestibility and lower fiber content to form base populations for the extraction of second cycle lines that have potential as new hybrids with high dry matter digestibility.

In a corn crop, the grain yield is a polygenic trait and is strongly influenced by the environment (Hallauer et al., 2010), with $\mathrm{h}_{\mathrm{a}}{ }^{2}$ estimates of 20\% (Idris and Abuali, 2011; Marcondes et al., 2016) to over 80\% (Barrière and Argillier, 1998; Bello et al., 2012; Ertiro et al., 2013). The $\mathrm{h}_{\mathrm{a}}^{2}$ values observed for grain yield were high in both our experiments, varying from $73.53 \%$ (Guarapuava) to $74.41 \%$ (Candói). These results indicate that most of the observed phenotypic variability comes from genetics, which can be exploited to make improvements.

Both general and specific combining ability (GCA and SCA, respectively) had a significant effect $(\mathrm{P}<0.05)$ on all traits evaluated in the trials conducted in Guarapuava and Candói (Table 2). This indicates that additive and non-additive genes control the traits related to silage production and its bromatological characteristics. These data corroborate the results from other studies (Ertiro et al., 2013; Guerrero et al., 2014; Mendes et al., 2015).

\section{General and specific combining ability}

The interaction between GCA and the environment was significant $(\mathrm{P}<0.05)$ for GY, PRO, FF, PH, and EH (Table 3). However, it is necessary to study the effect of the GCA of specific genotypes from each location because environmental differences are sufficient to affect the expression of additive genes involved in the control of these characteristics. However, the interaction between GCA and the environment was not significant for SD, and the result of the environment average satisfactorily explained the effects of the hybrid GCA (Table 3). The interaction between SCA and the environment was significant for all traits, and indicates that the expression of non-additive genes was modified by environmental variations in different locations.

Genetics and Molecular Research 16 (2): gmr16029643 
Table 3. Average Euclidian genetic distances standardized among 18 corn hybrids and Tocher modified agglomerative grouping to obtain agronomic and bromatological traits of silage quality in the Guarapuava (above diagonal) and Candói (below diagonal) assessment trials.

\begin{tabular}{|c|c|c|c|c|c|c|c|c|c|c|c|c|c|c|c|c|c|c|}
\hline & GNZ2004 & CD308 & Attack & CD304 & \begin{tabular}{|l|} 
AG8021 \\
\end{tabular} & SG6010 & \begin{tabular}{|l|} 
P30F53 \\
\end{tabular} & \begin{tabular}{|l|} 
P30B39 \\
\end{tabular} & \begin{tabular}{l|l|l|}
9 & P30K64 \\
\end{tabular} & \begin{tabular}{|l|l|}
4 & $\mathrm{P} 30 \mathrm{P} 4$ \\
\end{tabular} & Garra & \begin{tabular}{|l|} 
P30R50 \\
\end{tabular} & AG5011 & SG6015 & 2B688 & \begin{tabular}{|l|} 
AS1560 \\
\end{tabular} & AS1551 & AS1572 \\
\hline$\overline{\text { GNZ2004 }}$ & & 0.83 & 0.95 & 1.45 & 1.05 & 1.45 & 1.23 & 1.06 & 1.49 & 1.50 & 1.30 & 1.62 & 1.54 & 1.77 & 1.54 & 1.59 & 1.48 & 1.00 \\
\hline $\begin{array}{l}\text { CD308 } \\
\end{array}$ & 1.06 & & 0.95 & 1.51 & 1.41 & 1.21 & 1.29 & 0.90 & 1.39 & 1.12 & 1.23 & 1.11 & 1.64 & 1.62 & 1.34 & 1.55 & 1.10 & 1.04 \\
\hline Attack & 1.15 & 1.25 & & 1.10 & 1.12 & 1.29 & 1.36 & 1.06 & 1.26 & 1.44 & 1.43 & 1.47 & 1.23 & 1.45 & 1.19 & 1.48 & 1.42 & 0.87 \\
\hline CD304 & 1.81 & 2.00 & 1.54 & & 1.42 & 0.98 & 1.57 & 1.30 & 1.52 & 1.63 & 1.55 & 1.46 & 1.43 & 1.64 & 1.41 & 1.59 & 1.72 & 1.24 \\
\hline AG8021 & 1.08 & 1.20 & 0.99 & 2.01 & & 1.56 & 1.15 & 1.38 & 1.43 & 1.49 & 1.38 & 1.85 & 1.53 & 1.80 & 1.45 & 1.49 & 1.54 & 1.39 \\
\hline SG6010 & 1.43 & 1.77 & 1.24 & 1.85 & 1.64 & & 1.43 & 0.93 & 1.40 & 1.18 & 1.11 & 0.98 & 1.41 & 1.76 & 1.39 & 1.55 & 1.33 & 1.25 \\
\hline $\begin{array}{l}\text { P30F53 } \\
\end{array}$ & 1.38 & 1.60 & 1.38 & 1.65 & 1.50 & 1.51 & & 1.10 & 1.26 & 1.08 & 0.81 & 1.56 & 1.45 & 1.89 & 1.47 & 1.24 & 1.30 & 1.26 \\
\hline $\begin{array}{l}\text { P30B39 } \\
\end{array}$ & 1.25 & 1.03 & 1.09 & 1.88 & 1.12 & 1.45 & 1.04 & & 1.36 & 1.07 & 0.81 & 1.27 & 1.04 & 1.80 & 1.26 & 1.59 & 1.24 & 1.02 \\
\hline P30K64 & 1.11 & 1.34 & 0.92 & 1.58 & 1.31 & 1.27 & 0.66 & 0.87 & & 1.33 & 1.43 & 1.23 & 1.49 & 1.76 & 1.54 & 1.79 & 1.60 & 1.56 \\
\hline P30P34 & 1.63 & 1.61 & 1.85 & 2.21 & 1.69 & 1.84 & 1.27 & 1.42 & 1.43 & & 0.91 & 1.10 & 1.65 & 1.69 & 1.49 & 1.45 & 0.90 & 1.33 \\
\hline Garra & 1.71 & 1.53 & 1.44 & 2.00 & 1.55 & 1.53 & 1.12 & 1.10 & 1.12 & 1.04 & & 1.48 & 1.39 & 1.88 & 1.53 & 1.36 & 1.13 & 1.21 \\
\hline P30R50 & 1.22 & 1.42 & 1.15 & 1.59 & 1.14 & 1.47 & 0.68 & 1.10 & 0.85 & 1.18 & 1.11 & & 1.78 & 1.73 & 1.55 & 1.88 & 1.43 & 1.59 \\
\hline AG5011 & 1.56 & 1.69 & 1.20 & 2.15 & 1.26 & 1.54 & 1.34 & 1.33 & 1.20 & 1.73 & 1.48 & 1.02 & & 2.05 & 1.43 & 2.02 & 1.72 & 1.36 \\
\hline SG6015 & 0.85 & 0.80 & 1.29 & 1.99 & 1.13 & 1.62 & 1.34 & 1.14 & 1.24 & 1.53 & 1.48 & 1.05 & 1.45 & & 1.67 & 1.89 & 1.65 & 1.71 \\
\hline $2 \mathrm{~B} 688$ & 1.68 & 1.71 & 1.29 & 1.81 & 1.09 & 1.61 & 1.44 & 1.44 & 1.46 & 1.85 & 1.51 & 1.10 & 1.06 & 1.56 & & 1.56 & 1.48 & 1.24 \\
\hline AS1560 & 1.52 & 1.17 & 1.40 & 1.82 & 1.56 & 1.39 & 1.20 & 1.02 & 1.08 & 1.16 & 0.91 & 1.17 & 1.46 & 1.30 & 1.49 & & 1.40 & 1.20 \\
\hline AS1551 & 1.30 & 1.24 & 0.97 & 2.01 & 1.17 & 1.33 & 1.17 & 1.02 & 0.91 & 1.55 & 1.13 & 0.99 & 1.13 & 1.09 & 1.36 & 1.07 & & 1.33 \\
\hline AS1572 & 1.67 & 1.74 & 1.39 & 1.83 & 1.59 & 1.71 & 1.52 & 1.58 & 1.51 & 1.85 & 1.62 & 1.09 & 1.29 & 1.43 & 1.48 & 1.65 & 1.26 & \\
\hline \multicolumn{19}{|c|}{ Tocher modified grouping } \\
\hline \multicolumn{9}{|c|}{ Guarapuava } & \multirow{2}{*}{\multicolumn{10}{|c|}{$\begin{array}{l}\text { Candói } \\
\text { Hvbrids }\end{array}$}} \\
\hline Group & \multicolumn{8}{|c|}{ Hybrids } & Group & & & & & & & & & \\
\hline & \multicolumn{8}{|c|}{$\begin{array}{l}\text { CD308, Attack, AS1572, GNZ2004, P30B39, AG5011, Garra, P30F53, } \\
\text { CD304, SG6010,AS1551,P30P34 }\end{array}$} & I & \multicolumn{9}{|c|}{$\begin{array}{l}\text { P30F53, P30K64, P30R50,P30B39, AS1551, Attack,AS1560,Garra, SG6015, CD308, } \\
\text { GNZ2004, AG8021, AG5011, 2B B688, SG6010,AS1572,P30P34 }\end{array}$} \\
\hline II & \multirow{2}{*}{\multicolumn{8}{|c|}{$\frac{\mathrm{P} 30 \mathrm{~K} 64, \mathrm{P} 30 \mathrm{R} 50,2 \mathrm{~B} 688, \mathrm{AG} 8021, \mathrm{AS} 1560}{\mathrm{SG} 6015}$}} & II & \multirow{2}{*}{\multicolumn{9}{|c|}{ CD304 }} \\
\hline III & & & & & & & & & & & & & & & & & & \\
\hline
\end{tabular}

The estimates of hybrid GCA $\left(\hat{\mathrm{g}}_{\mathrm{i}}\right)$ effects on the agronomic and bromatological aspects of silage quality are shown on Figures 1 to 3. Thus, for GMY, DMY, CP, and IVDMD, it is important that $\hat{\mathrm{g}}_{\mathrm{i}}$ estimates are positive and of high magnitude because it is desirable that the phenotypic value of these characteristics be increased. However, it is desirable to decrease NDIF and ADIF so that the $\hat{g}_{i}$ estimates are negative and of high magnitude.
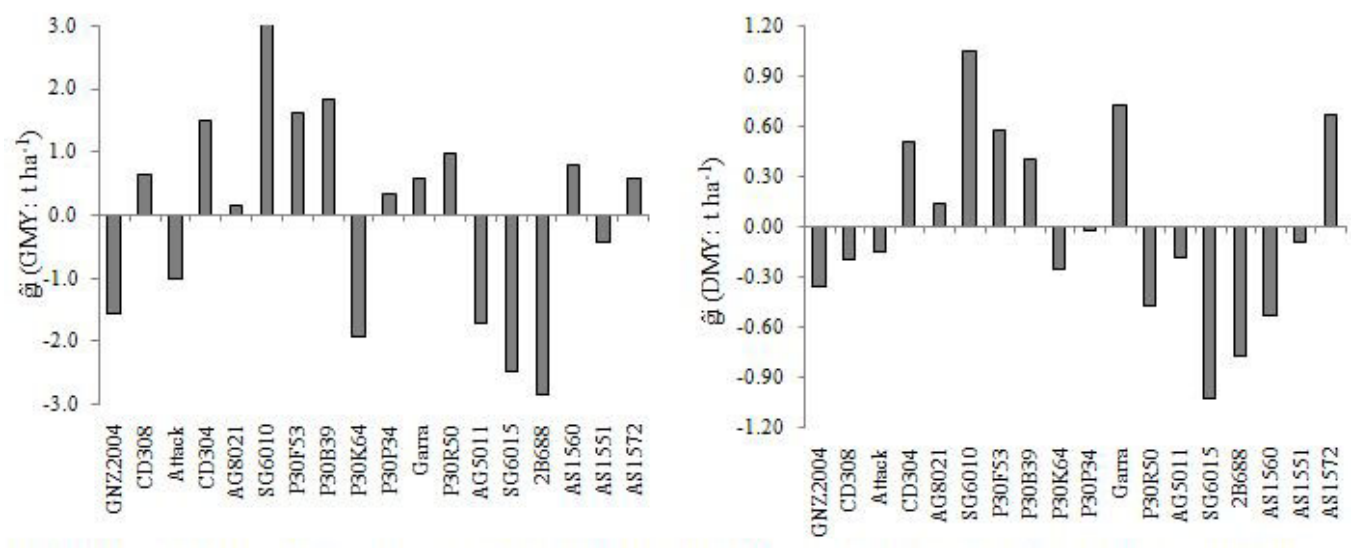

Figure 1. Effects of general combining ability $\left(\hat{g}_{i}\right)$ of 18 corn field maize hybrids to traits: green mass yield (GMY: t/ha), dry matter yield (DMY: t/ha).

When aiming to increase forage green mass yield at the point of silage, the recommended hybrids for intrapopulation enhancement are SG6010, P30F35, and CD304 because, on average, they were capable of increasing GMY in crosses with the participation of genitors owing to the high frequency of additive genes (Figure 1). For DMY, the hybrids with

Genetics and Molecular Research 16 (2): gmr16029643 

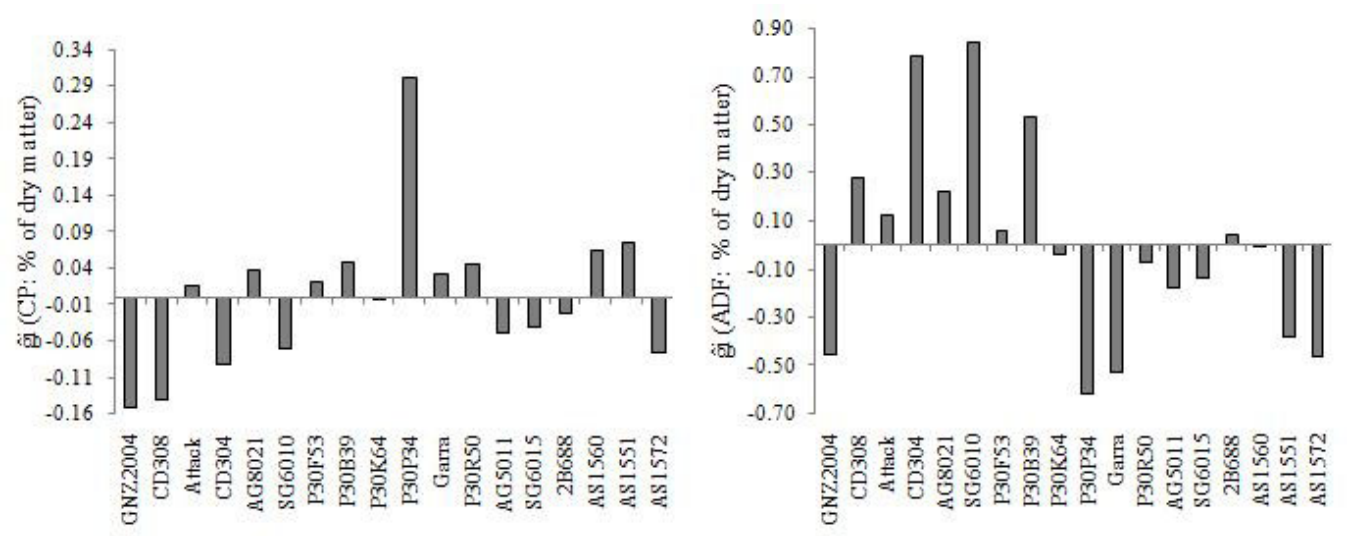

Figure 2. Effects of general combining ability $\left(\hat{g}_{i}\right)$ of 18 corn field maize hybrids to traits: crude protein (CP: \% of dry matter), acid detergent fiber (ADF: $\%$ of dry matter).
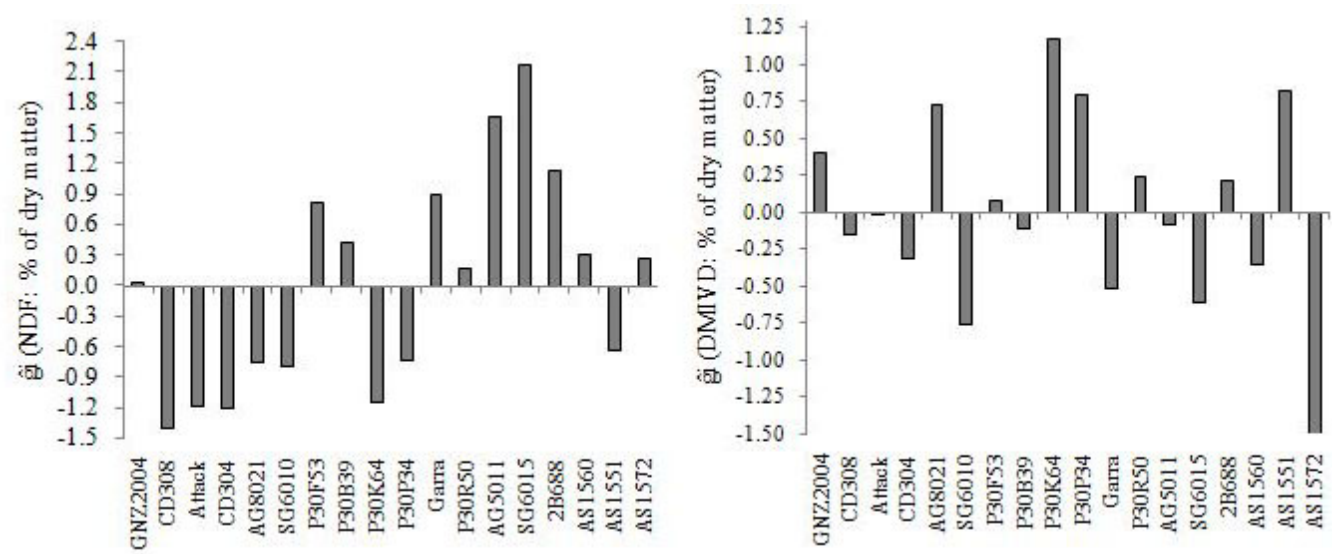

Figure 3. Effects of general combining ability $\left(\hat{g}_{i}\right)$ of 18 corn field maize hybrids to traits: neutral fiber detergent (NDF: \% of dry matter), dry matter in vitro digestibility (DMIVD: \% of dry matter).

higher $\hat{g}_{i}$ estimates in ascending order are SG6010, Garra, and AS1572 because they provide increments of dry matter yield of the forage at the point of silage in the crosses that were used as genitors, and are the most promising for intrapopulational improvement (Figure 1).

Corn hybrids with higher crude protein content provide economic external sources and encourage greater activity of the rumen microorganisms in the animals that digest the silage. Figure 2 shows that the $\mathrm{P} 30 \mathrm{P} 34$ hybrid was the only outstanding genitor regarding $\mathrm{CP}$ increments in silage, and showed an average $0.30 \%$ increase in protein in the crosses it participated in.

Breeding programs for forage corn have involved searches to select germplasms that contribute to greater participation of grains in silage mass; they provide lower fiber content and therefore result in silage with higher digestibility and nutritional value. Thus, based on $\hat{g}_{i}$ estimates, we recommend that in future researchers try to reduce the ADIF content of hybrids P30P34, Garra, AS1572, and GNZ2004 for intrapopulational strategy breeding (Figure 2). 
However, regarding NDIF content, we recommend the genitors CD308, Attack, CD304, P30K64, and P30P34 for intrapopulational breeding because they are capable of reducing NDIF content in the crosses in which they participate as genitors (Figure 3).

Hybrids P30K64, P30P34, AS1551, and AG8021 showed positive $\hat{g}_{\mathrm{i}}$ estimates for IVDMD owing to a higher frequency of favorable and additive-effect alleles that increased the digestibility of the silage in the crosses in which they were genitors (Figure 3).

Some hybrids stood out with $\hat{\mathrm{g}}_{\mathrm{i}}$ estimates appropriate for intrapopulational breeding strategies for more than one trait. Thus, when aiming to form a base population for intrapopulational recurrent selection searching to improve traits related to the silage bromatological quality, hybrid P30P34 stood out because it presented favorable $\hat{\mathrm{g}}_{\mathrm{i}}$ estimates and contributed to additive effect genes to improve DS, NDIF, ADIF, and IVDMD. Hybrid P30P34 has the potential for use in silage production, and was also recommended by Gralak et al. (2014) and de Souza Neto et al. (2015) for forming populations for intrapopulational recurrent selection of corn for silage, with the aim of reducing fiber content and improving the nutritional quality of the silage.

Hybrids CD304 and SG6010 can also be recommended for intrapopulational recurrent selection in consideration of GMY and DMY. Hybrid AS1572 had satisfactory $\hat{\mathrm{g}}_{\mathrm{i}}$ estimates for the improvement of NDIF and DMY. However, hybrid P30K64 can be used in breeding programs that attempt to reduce NDIF content and increase IVDMD.

The concept of SCA refers to non-additive-effect genes, contributes to the expression of the traits, and is of extreme importance for interpopulational improvement strategies (reciprocal recurrent selection) (Cruz et al., 2012). Thus, the best hybrid combination for breeding regarding SCA effects is the one that has $\hat{\mathrm{S}}_{\mathrm{ij}}$ estimates of appropriate magnitude for improving the feature. In addition, at least one of the genitors must have an appropriated $\hat{\mathrm{S}}_{\mathrm{ij}}$ because, regarding qualitative and polygenic traits, additive and non-additive effects influence the final expression of the characteristic.

When the aim of the breeder is to form populations for reciprocal recurrent selection (interpopulational strategies) by searching to select lines that will simultaneously provide hybrids with higher GMY and DMY, we recommend a combination of hybrids SG6010 and 2B688. Both genitors show $\hat{\mathrm{S}}_{\mathrm{ij}}$ estimates that are favorable for improving GMY $(8.62 \mathrm{t} / \mathrm{ha})$ and DMY (2.33 t/ha), and both have as a genitor the hybrid SG6010, which stands out for its $\hat{S}_{\mathrm{i}}$ effects on these traits. When the aim is to increase the CP content of the silage, the best hybrid combination is P30P34 and AS1560 because it has the highest $\hat{\mathrm{S}}_{\mathrm{ij}}$ estimate of diallel and also because genitor P30P34 stands out for its $\hat{\mathrm{g}}_{\mathrm{i}}$ for CP.

For interpopulational breeding schemes, when the aim is to reduce the ADIF content of the silage, the recommended combinations are P30P34 and AS1572 $\left(\hat{\mathrm{S}}_{\mathrm{ij}}=-2.68 \%\right)$, and Garra and GNZ2004 $\left(\hat{\mathrm{S}}_{\mathrm{ij}}=-2.29 \%\right)$, in which the genitor hybrids show favorable $\hat{\mathrm{g}}_{\mathrm{i}}$ effects for reducing ADIF content. However, when the aim is to form populations for interpopulational breeding schemes for decreasing NDIF content, the recommended combinations are CD308 and P30F53 $\left(\hat{\mathrm{S}}_{\mathrm{ij}}=-6.08 \%\right), \mathrm{P} 30 \mathrm{~K} 64$ and AS1551 $\left(\hat{\mathrm{S}}_{\mathrm{ij}}=-4.28 \%\right)$, and Attack and P30B39 $\left(\hat{\mathrm{S}}_{\mathrm{ij}}=\right.$ $-3.65 \%$ ) because they have at least one genitor with favorable $\hat{\mathrm{g}}_{\mathrm{i}}$ effect.

The genitor combinations P30P34 and AS1572 $\left(\hat{\mathrm{S}}_{\mathrm{ij}}=4.40 \%\right)$, and AS1572 and P30K64 $\left(\hat{\mathrm{S}}_{\mathrm{ij}}=2.07 \%\right)$ deserve more consideration when the aim is to increase the IVDMD of silage in interpopulational breeding schemes, because such populations have positive $\hat{S}_{i j}$ values and all the genitor hybrids are selected according to $\hat{g}_{i}$ effects that are appropriate for IVDMD enhancement.

Genetics and Molecular Research 16 (2): gmr16029643 
Estimates of general combining ability for agronomic traits in Guarapuava and Candói can be seen in Figures 4 to 6 . The hybrids P30B39, P30K64, and 2B688 show positive $\hat{\mathrm{g}}_{\mathrm{i}}$ effects and high magnitude in both locations, and there are considerable increases in GY in the crosses in which they participated as genitors. This is owing to the presence of favorable additive-effect alleles (Figure 4).
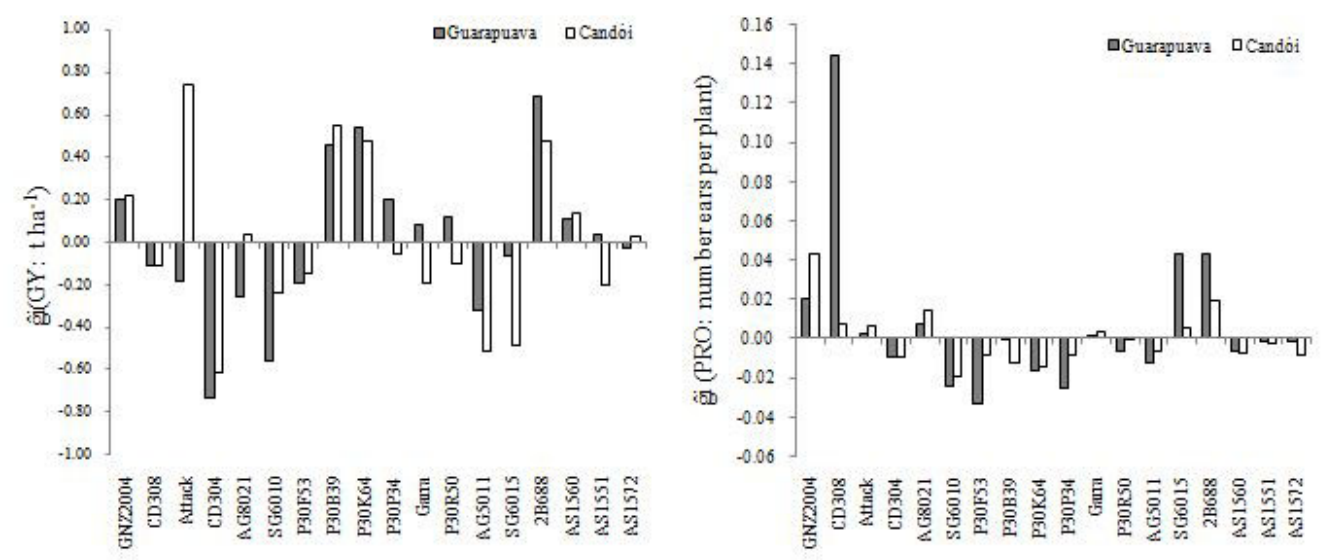

Figure 4. Effects of general combining ability $\left(\hat{g}_{i}\right)$ of 18 corn field genitor hybrids assessment in Guarapuava and Candói enviroments to traits: grain yield (GY: t/ha), prolificacy: (PRO: number of ears per plant).
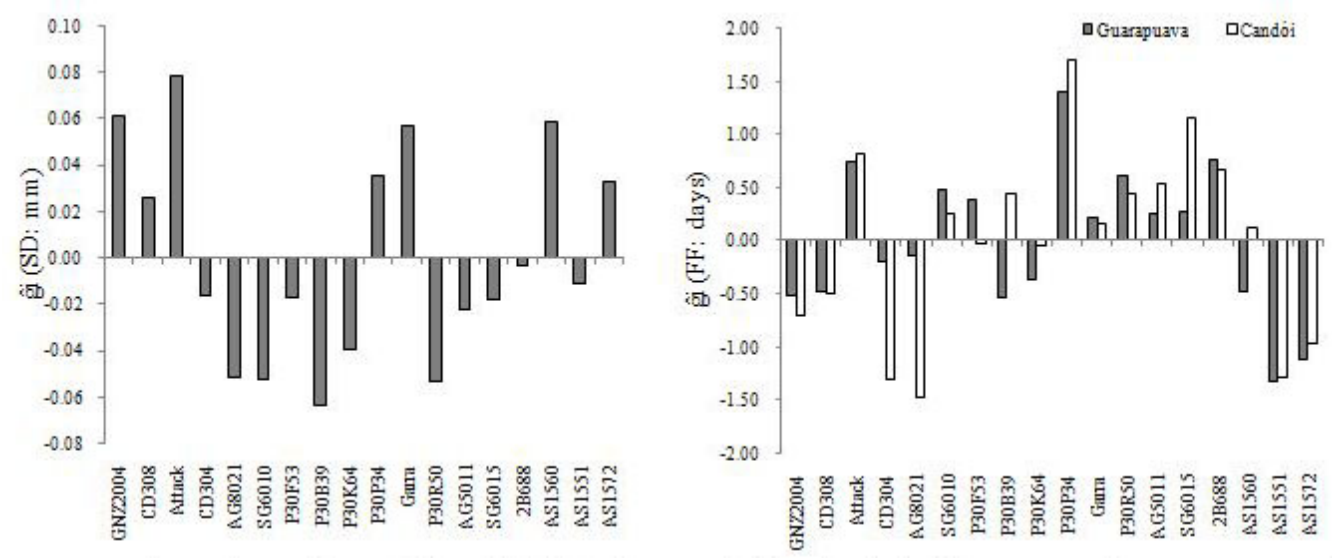

Figure 5. Effects of general combining ability $\left(\hat{g}_{i}\right)$ of 18 corn field genitor hybrids assessment in Guarapuava and Candói enviroments to traits: stem diameter (SD: $\mathrm{mm}$ ), female flowering (FF: days).

We emphasize the importance of the interaction between the genotype and the environment with regard to the choice of genitors that will form base populations, because the Attack hybrid stood out regarding ĝi effects only in Candói, whereas in Guarapuava it presented a negative gi (Figure 4). The genetic merit of the simple 2B688 hybrid for the formation of a base population for the intrapopulation enhancement of GY was also highlighted

Genetics and Molecular Research 16 (2): gmr16029643 
by Oliboni et al. (2013). In the present study, apart from 2B688, hybrids P30P39 and P30K64 showed satisfactory behavior in both environments, and are alternatives for the formation of base populations for increasing GY. However, for interpopulational breeding schemes, the combination of genitors P30B39 and 2B688 stood out because it showed favorable $\hat{S}_{\mathrm{ij}}$ effects for increasing GY in both Guarapuava and Candói trails, in which genitor hybrids showed favorable $\hat{g}_{\mathrm{i}}$ estimates for both environments (Figure 4).
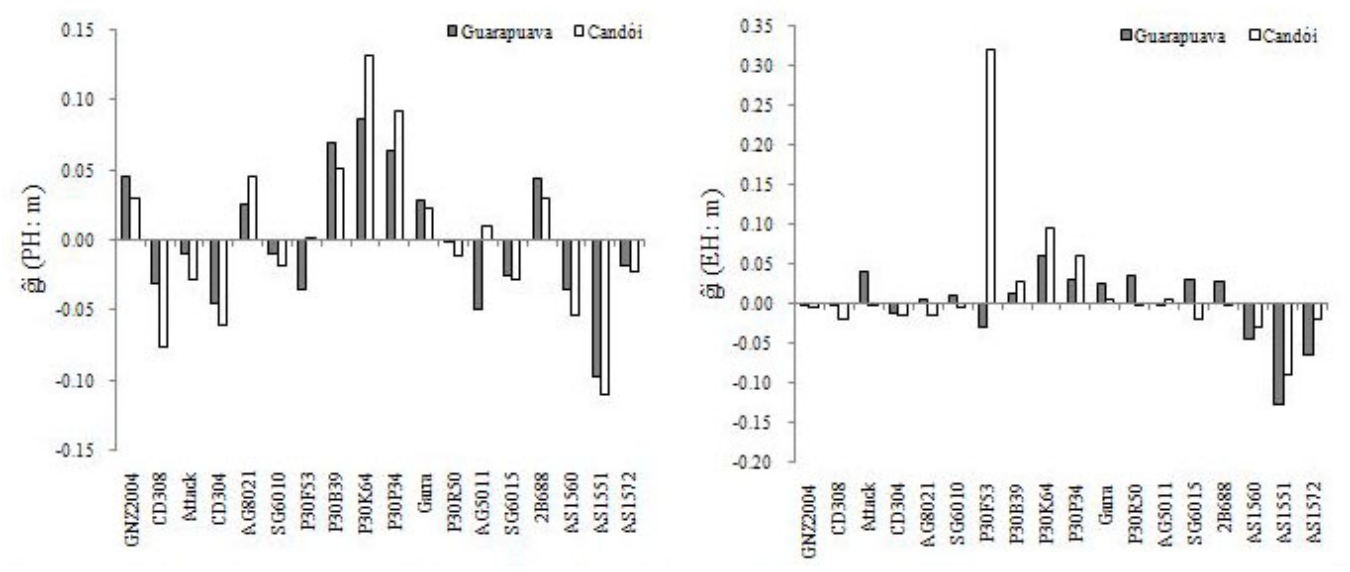

Figure 6. Effects of general combining ability $\left(\hat{g}_{i}\right)$ of 18 corn field genitor hybrids assessment in Guarapuava and Candói enviroments to traits: plant heigh (PH: $\mathrm{m})$, and ear insertion height (EH: $\mathrm{m})$.

Because the interaction between GCA and the environment had no significant effect on $\mathrm{SD}$, it is clear that environmental differences do not affect the expression of additive-effect genes that are involved in the expression of such features. Therefore, the joint analysis of the average environment is sufficient for the selection of genitors. Thus, hybrids P30B39, P30R50, AG8021, and SG6015 had large negative $\hat{g}_{i}$ estimates that contributed to the reduce in thatch diameter (Figure 5). However, the interaction between SCA and the environment was significant; the best combinations for interpopulation enhancement in Guarapuava were P30F53 and AG8021, and GNZ2004 and SG6010, whereas those in Candói were AG8021 and AS1560, and Attack and P30R50.

The best genitors for FF effects $\left(\hat{\mathrm{g}}_{\mathrm{i}}\right)$ with regard to prolificacy in both environments were AS1572 and AS1551, and they contributed to female flowering in crosses in which they were genitors (Figure 5). With respect to interpopulation enhancement with the aim of increasing prolificacy, in Guarapuava, the highlighted crosses were P30R50 and AS1572, and P30F53 and AS1551. In Candói the highlighted crosses were AG8021 and P30P34 because both presented at least one genitor with a satisfactory $\hat{g}_{\mathrm{i}}$ effect and a large negative $\hat{\mathrm{S}}_{\mathrm{ij}}$.

Hybrids CD308, CD304, and AS1551 contributed to size reduction and stood out for their $\hat{\mathrm{g}}_{\mathrm{i}}$ effects in both environments. Therefore, we recommend them for intrapopulation enhancement when searching for smaller plants (Figure 6). However, with regard to the formation of populations for interpopulational improvement schemes with the aim of decreasing the size of the plants, we recommend combinations CD304 and P30K64, and AG8021 and AS1551 for Guarapuava, and CD304 and P30K60, and CD304 and AS1551 for Candói. To generate populations for the intrapopulation improvement of the height of cob

Genetics and Molecular Research 16 (2): gmr16029643 
insertion, the highlighted hybrids were AS1560, AS1551, and AS1572 with regard to the gi effects (Figure 6). The best populations for interpopulation enhancement based on data from both experiments came from the combination of P30B39 and AS1572.

\section{Genetic divergence and correlations}

The success of a corn breeding program that involves a search for superior hybrids depends in particular on the population base formation stage (Hallauer et al., 2010). It is recommended that new base populations are not formed based only on their phenotype, adaptation, and the resistance of their genitors, but on other genetic parameters such as reduced inbreeding, combining ability, and genetic distance (Oliboni et al., 2013; de Souza Neto et al., 2015; Senhorinho et al., 2015).

There are several multivariate methods for successfully predicting genetic distance between genitors involving the main elements, canonical variables, and Tocher's method (Cruz et al., 2012). Oliboni et al. (2012) estimated genetic distance using multivariate techniques with genetic parameters obtained for diallel crosses between commercial corn hybrids. These authors affirmed that such techniques are important tools for understanding heterotic groups in corn breeding programs, and they contribute to the prediction of promising crosses and the formation of improved base populations.

Values above the main diagonal in Table 4 represent genetic distances among 18 corn hybrids obtained by the mean Euclidean standard distance based on 12 agronomic and bromatological traits of the quality of corn silage evaluated in Guarapuava. The average genetic distance among the 18 hybrids was of 1.39 and the most divergent hybrid pairs were AG5011 and SG6015, and AG6015 and SG1560, with genetic distances of 2.05 and 2.02, respectively. These combinations provide evidence for possible heterotic groups. The most genetically similar hybrids were Garra and P30F53, Garra and P30B39, and CD308 and GNZ2004. The combination of such hybrids tends to generate populations with reduced variability.

The highest mean genetic distance was between SG6015 and 2B688, coinciding with Tocher's modified grouping that placed these two hybrids in two different groups (Table 4). The three combinations with highest GY were obtained from hybrid 2B688 crossed with P30F53 (12.03 t/ha), P30B39 (11.82 t/ha), and P30K64 (11.19 t/ha). This indicates that 2B688 increased GY by virtue of its genetic distance from the others.

The grouping of the 18 corn hybrids by Tocher's modified method based on genetic distances obtained in the Guarapuava trial showed the formation of three mutually exclusive groups (Table 4). Consequently, the individuals that belong to the same group are genetically similar and the genetic variability must be at a maximum when crosses are performed between individuals of different groups. Group I included hybrids CD308, Attack, AS1572, GNZ2004, P30B39, AG5011, Garra, P30F53, CD304, SG6010, AS1551, and P30P34 (Table 4) from various enhancement companies. Group II included hybrids P30K64, P30R50, 2B688, AG8021, and AS1560, and in Group III, the hybrid SG6015 was isolated from the other evaluated hybrids and was considered the most genetically distant hybrid. Simple hybrid SG6015 has toothed grains and an early cycle, and can be used in the production of grains and whole plant silage, producing silage of high dry matter digestibility (Table 1).

Genetic divergence among individuals must always be analyzed with SCA when aiming to form base populations with high phenotypic mean and wide genetic variability. In the Guarapuava trial, the analysis of genetic distance and SCA among hybrids 2B688, P30F53, P30B39, and P30K64 indicates the feasibility of the reciprocal recurrent selection strategy

Genetics and Molecular Research 16 (2): gmr16029643 
among populations generated from 2B688 and the other hybrids, because the SCA was large in such combinations. In reciprocal recurrent selection, one population acts as the tester of the other population, and during the selection cycles, SCA and heterosis among populations increase, producing superior hybrids through the combination of population lines derived from 2B688 with lines derived from P30F53, P30K64, and P30B39.

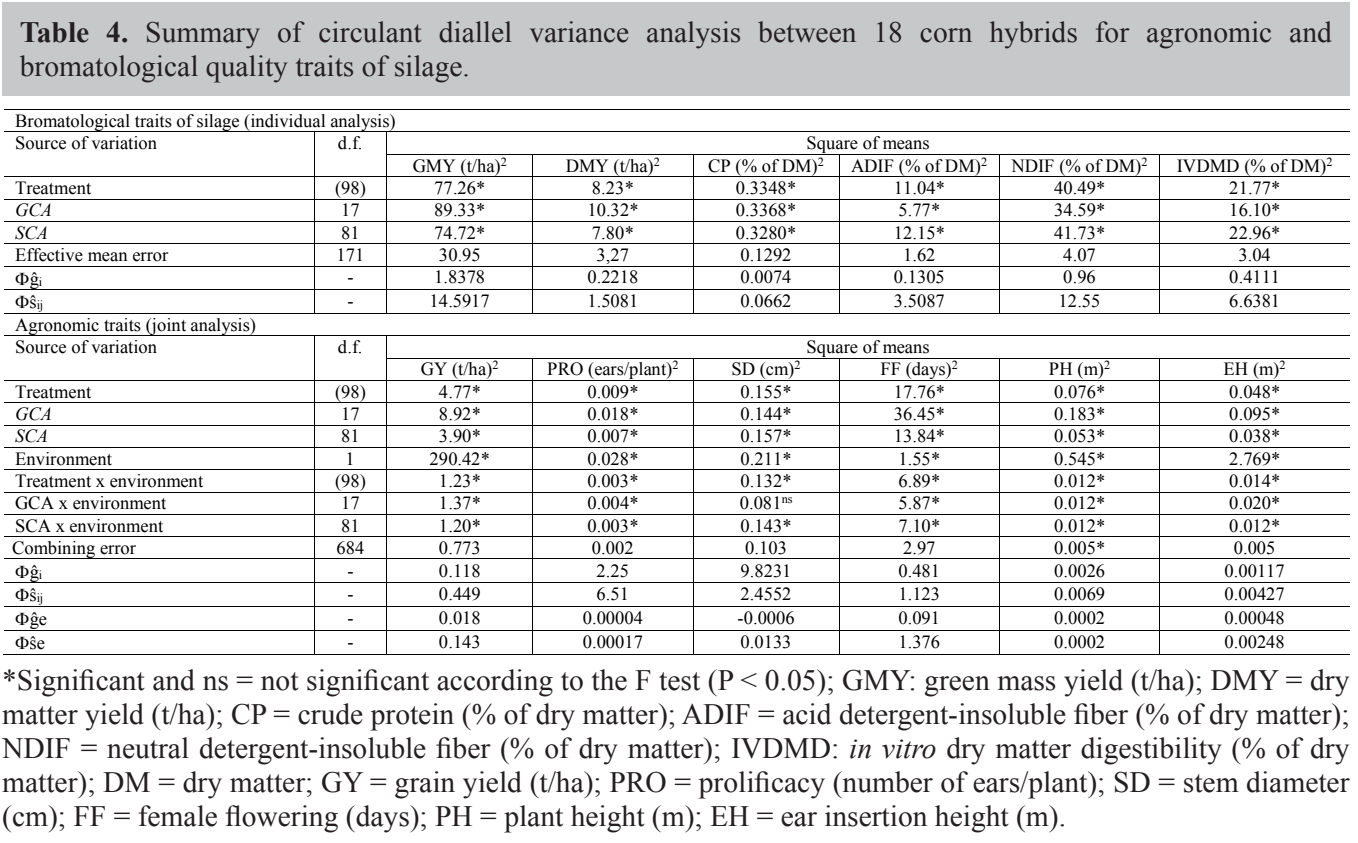

Distance values under the diagonal in Table 4 are related to the Candói trial. The average genetic distance observed among the 18 hybrids was of 1.38 , very close to the one observed in Guarapuava. The biggest genetic distance was 2.21 between CD304 and P30P34. Combinations P30F53 and P30K64, and P30F53 and P30R50 had the smallest genetic distances because they were provided by the same company and possibly had the same genetic basis.

The P30P34 hybrid was the most genetically distant genitor (Table 4), with an average distance was 1.74. Crosses P30P34 and Attack, and P30B39 and 2B688 produced double hybrids with higher GY values in the Candói trial: $14.02 \mathrm{t} / \mathrm{ha}$, which surpassed the genitors and the commercial check DKB330. The closest hybrids in terms of genetics were AS1551 and SG6010 with a distance of 1.24 (Table 4). In the Candói trial, grouping by Tocher's modified method produced only two groups. In group I, 17 hybrids were included and in group II the CD304 hybrid remained isolated. The combination of 2B688 and P30B39 showed satisfactory performance and had a large positive SCA in both experiments, which confirms the strategy of using these hybrids to generate base populations for reciprocal recurrent selection.

In the Guarapuava trial, the Spearman coefficient classificatory correlation was not significant $(\mathrm{P}<0.05)$ among the genetic distances of the 18 genitor hybrids in the circulant diallel scheme and the GY of the related double hybrids. This indicates that when crossed, the genitors with the largest genetic distances do not tend to originate a combination of higher means (Table 5). In the Candói trial, there was significant correlation $(\mathrm{P}<0.05)$ among the 
genetic distances of genitors and the SCA of GY. These results corroborate the affirmation that a cross with high SCA must have a parent with a high degree of genetic divergence with dominant effects on the control character (Miranda Filho and Gorgulho, 2001). Other studies on the use of genetic distance for the prediction of genetic parameters such as heterosis and SCA do not corroborate our present results.

Table 5. Classificatory Spearman correlation among standardized average Euclidian genetic distances, genetic parameter means, and specific combining ability observed in corn hybrids obtained for the circulant diallel scheme for agronomic and bromatological quality traits of silage assessment in the Guarapuava and Candói environments.

\begin{tabular}{|c|c|c|c|c|c|}
\hline \multirow[t]{2}{*}{ Trait } & \multirow[t]{2}{*}{ Parameter genetic } & \multicolumn{2}{|c|}{ Guarapuava } & \multicolumn{2}{|c|}{ Candói } \\
\hline & & Average & $\hat{\mathrm{S}}_{\mathrm{ij}}$ & Average & $\hat{\mathrm{S}}_{\mathrm{ij}}$ \\
\hline \multirow{2}{*}{ GY } & DEMP & 0.25 & -0.06 & 0.03 & $0.31^{*}$ \\
\hline & average & - & $0.79 *$ & - & $0.77^{*}$ \\
\hline \multirow[t]{2}{*}{$\mathrm{FF}$} & DEMP & 0.18 & 0.11 & -0.10 & -0.09 \\
\hline & average & - & $0.78^{*}$ & - & $0.73^{*}$ \\
\hline \multirow[t]{2}{*}{ SD } & DEMP & -0.04 & 0.09 & $0.23 *$ & 0.09 \\
\hline & average & - & $0.77 *$ & - & $0.93^{*}$ \\
\hline \multirow[t]{2}{*}{$\mathrm{PH}$} & DEMP & -0.12 & -0.02 & 0.07 & 0.15 \\
\hline & average & - & $0.76^{*}$ & - & $0.78^{*}$ \\
\hline \multirow[t]{2}{*}{$\mathrm{EH}$} & DEMP & -0.01 & -0.02 & 0.04 & 0.02 \\
\hline & average & - & $0.76^{*}$ & - & $0.87^{*}$ \\
\hline \multirow[t]{2}{*}{ GMY } & DEMP & 0.07 & 0.043 & - & - \\
\hline & average & - & 0.06 & - & - \\
\hline \multirow[t]{2}{*}{ DMY } & DEMP & -0.16 & -0.07 & - & - \\
\hline & average & - & 0.09 & - & - \\
\hline \multirow[t]{2}{*}{$\mathrm{CP}$} & DEMP & 0.06 & 0.02 & - & - \\
\hline & average & - & 0.07 & - & - \\
\hline \multirow[t]{2}{*}{ NDIF } & DEMP & -0.14 & -0.05 & - & - \\
\hline & average & - & 0.11 & - & - \\
\hline \multirow[t]{2}{*}{ ADIF } & DEMP & -0.01 & -0.07 & - & - \\
\hline & average & - & 0.01 & - & - \\
\hline \multirow[t]{2}{*}{ LDA } & DEMP & 0.03 & -0.02 & - & - \\
\hline & average & - & 0.08 & - & - \\
\hline
\end{tabular}

*Significant and $\mathrm{ns}=$ not significant according to the $t$-test $(\mathrm{P}<0.05) ; \mathrm{GY}=$ grain yield $(\mathrm{t} / \mathrm{ha}) ; \mathrm{FF}=$ female flowering (days); $\mathrm{SD}=$ stem diameter $(\mathrm{cm}) ; \mathrm{PH}=$ plant height $(\mathrm{m}) ; \mathrm{EH}=$ ear insertion height; GMY = green mass yield (t/ha); $\mathrm{DMY}=$ dry matter yield $(\mathrm{t} / \mathrm{ha}) ; \mathrm{CP}=$ crude protein $(\%$ of dry matter $) ; \mathrm{NDIF}=$ neutral detergent-insoluble fiber $(\%$ of dry matter); ADIF = acid detergent-insoluble fiber ( $\%$ of dry matter $)$.

Fernandes et al. (2015) verified the absence of genetic distance correlation among 48 elite corn lines using simple sequence repeat (SSR) molecular markers and the performance of hybrids. However, the authors suggest that extreme genetic distance data should be used for the choice of more promising crosses once the best hybrids have been obtained by the combination of lines with bigger genetic distances.

Oliboni et al. (2012) evaluated genetic divergence among 12 corn hybrids used as genitors in a complete diallel scheme, and did not observe significant positive correlations between genetic distance and the genetic parameters used in the formation of base populations. They concluded that genetic divergence is not sufficient to account for the heterosis observed in hybrids once the occurrence of heterosis also depends on the degree of dominance of the considered characteristic. However, these authors evaluated 22 variables of qualitative and quantitative nature, and did not use the tool for multicollinearity diagnosis that all ows the selection of variables for the study of genetic divergence, thereby avoiding analysis of the grouping of highly correlated variables that may influence the separation of the groups.

In the Guarapuava trial, we did not observe correlation between the genetic distances of the 18 hybrids and SCA or the observed mean for all the silage agronomic and bromatological traits. These results are different from the ones obtained by Melchinger et al. (1992), who 
estimated the genetic distance among 12 corn lines with different grain textures using restriction fragment length polymorphism (RFLP) molecular markers. They concluded that there was a large positive association between the genetic distances observed in the corn lines and the CEC of hybrids from such crosses.

There were large, positive, and significant correlations $(\mathrm{P}<0.05)$ between SCA and the means of GY, FF, DS, PH, and EH in the Guarapuava and Candói trials (Table 5), which corroborates other studies (Oliboni et al., 2012). Such results indicate that the crosses with higher means tend to have higher deviations regarding their genitors, which means they present a higher degree of allelic complementarity with each other.

According to the results, we can conclude that the 2B688 hybrid forms the best base population for an intrapopulational breeding program for grain yield. The hybrids P30B39 and 2B688 are the best for obtaining populations for an interpopulational breeding scheme. The hybrid P30P34 is recommended for intrapopulational breeding when the aim is to obtain silage with higher crude protein content, lower fiber content, and better in vitro dry matter digestibility. For interpopulational breeding, when the aim is to improve silage digestibility, we recommend hybrids P30P34 and AS1572, and hybrids AS1572 and P30K64. The hybrids 2B688, P30P34, and SG6015 are the most genetically distant from the others and have appreciable values for combining ability, and are important genitors for the formation of new base populations for silage corn breeding programs.

\section{Conflicts of interest}

The authors declare no conflict of interest.

\section{ACKNOWLEDGMENTS}

The authors are grateful to CNPq, Capes and Finep by all financial support.

\section{REFERENCES}

Argillier O, Barrière Y, Panel A, Aziac B, et al. (1998). Variability of digestibility criteria in maize elite hybrids submitted for registration in the French official catalogue. Agronomie 18: 639-648. http://dx.doi.org/10.1051/agro:19981003

Argillier O, Méchin V and Barriére Y (2000). Inbred line evaluation and breeding for digestibility-related traits in forage maize. Crop Sci. 40: 1596-1600. http://dx.doi.org/10.2135/cropsci2000.4061596x

Barrière Y and Argillier O (1998). In vivo silage feeding value of early maize hybrids registered in France between 1958 and 1994. Euphytica 99: 175-182. http://dx.doi.org/10.1023/A:1018379931874

Bello OB, Ige SA, Azeez MA, Afolabi MS, et al. (2012). Heritability and genetic advance for grain yield and its components characters in maize (Zea mays L.). Int. J. Plant Res. 02: 138-145. http://dx.doi.org/10.5923/j.plant.20120205.01

Cruz CD (2013). Genes - a software package for analysis in experimental statistics and quantitative genetics. Acta Sci. Agron. 35: 271-276. http://dx.doi.org/10.4025/actasciagron.v35i3.21251

Cruz CD, Regazzi AJ and Carneiro PCS (2012). Modelos biométricos aplicados ao melhoramento genético. UFV, Viçosa.

de Oliveira FCL, Jobim CC, da Silva MS, Calixto Jr M, et al. (2011). Productivity and nutritional value of silage of corn hybrids with different heights of harvest. Rev. Bras. Zootec. 40: 720-727.

de Souza Neto IL, Pinto RJB, Scapim CA, Jobim CC, et al. (2015). Diallel analysis and inbreeding depression of hybrid forge corn for agronomic traits and chemical quality. Bragantia 74: 42-49.

Ertiro BT, Zeleke H, Friesen D, Blummel M, et al. (2013). Relationship between the performance of parental inbred lines and hybrids for food-feed traits in maize (Zea mays L.) in Ethiopia. Field Crops Res. 153: 86-93. http://dx.doi. org/10.1016/j.fcr.2013.02.008

Fernandes EH, Schuster I, Scapim CA, Vieira ES, et al. (2015). Genetic diversity in elite inbred lines of maize and its association with heterosis. Genet. Mol. Res. 14: 6509-6517. http://dx.doi.org/10.4238/2015.June.12.3

Genetics and Molecular Research 16 (2): gmr16029643 
Gomes MS, Von Pinho RG, Ramalho MAP, Ferreira DV, et al. (2004). Variabilidade genética em linhagens de milho nas características relacionadas com a produtividade de silagem. Pesqui. Agropecu. Bras. 39: 879-885. http://dx.doi. org $/ 10.1590 /$ S0100-204X2004000900007

Gralak E, Faria MV, Possato O, Junior., Rossi ES, et al. (2014). Capacidade combinatória de híbridos de milho para caracteres agronômicos e bromatológicos da silagem. Rev. Bras. Milho e Sorgo 13: 187-200. http://dx.doi. org/10.18512/1980-6477/rbms.v13n2p187-200

Guerrero CG, Robles MAG, Ortega JGL, Castillo IO, et al. (2014). Combining ability and heterosis in corn breeding lines to forage and grain. Am. J. Plant Sci. 5: 845-856. http://dx.doi.org/10.4236/ajps.2014.56098

Hallauer AR, Carena MJ and Miranda Filho JB (2010). Quantitative genetics in maize breeding. Springer-Verlag, New York.

Idris AE and Abuali AI (2011). Genetic variability for vegetative and yield traits in maize (Zea mays L.) genotypes. Int. Res. J. Agric. Sci. Soil Sci. 01: 408-411.

Kempthorne O and Curnow RN (1961). The partial diallel cross. Biometrics 17:229-250. http://dx.doi.org/10.2307/2527989

Krakowsky MD, Lee M and Coors JG (2006). Quantitative trait loci for cell wall components in recombinant inbred lines of maize (Zea mays L.) II: leaf sheath tissue. Theor. Appl. Genet. 112: 717-726. http://dx.doi.org/10.1007/s00122$\underline{005-0175-0}$

Marcondes MM, Faria MV, Neumann M, Marcondes MM, et al. (2015). Agronomic performance and forage quality of S4 corn lines in topcrosses with single cross hybrid. Semin. Cienc. Agrar. 36: 2395-2406. http://dx.doi.org/10.5433/1679$\underline{0359.2015 \mathrm{v} 36 \mathrm{n} 4 \mathrm{p} 2395}$

Marcondes MM, Faria MV, Mendes MC, Gabriel A, et al. (2016). Breeding potential of $\mathrm{S}_{4}$ maize lines in topcrosses for agronomic and forage traits. Acta Sci. Agron. 03: 307-315. http://dx.doi.org/10.4025/actasciagron.v38i3.28307

Mendes MHS, Pereira CH and de Souza JC (2015). Diallel analysis of maize hybrids for agronomic and bromatological forage traits. Acta Sci. Agron. 37: 141-146. http://dx.doi.org/10.4025/actasciagron.v37i2.19329

Melchinger AE, Boppenmaier J, Dhillon BS, Pollmer WG, et al. (1992). Genetic diversity for RFLPs in European maize inbreds: II. Relation to performance of hybrids within versus between heterotic groups for forage traits. Theor. Appl. Genet. 84: 672-681.

Miranda Filho JB and Gorgulho EP (2001). Cruzamentos com testadores e dialelos. In: Recursos Genéticos e Melhoramento de Plantas (Nass LL, Valois ACC, Melo IS and Valadares-Inglis MC, eds.). Fundação MT, Rondonópolis, 649-671.

Neumann M, Restle J, Mühlbach PRF, Nörnberg JL, et al. (2009). Intake and activity behavior of steers finished in feedlot with corn silages of different particle sizes and cutting heights. Ciência Animal Brasileira 10: 462-473.

Oliboni R, Faria MV, Neumann M, Battistelli GM, et al. (2012). Genetic divergence among maize hybrids and correlations with heterosis and combining ability. Acta Sci. Agron. 34: 37-44. http://dx.doi.org/10.4025/actasciagron.v34i1.11979

Oliboni R, Faria MV, Neumann M, Resende JTV, et al. (2013). Diallelic analysis in assessing the potential of maize hybrids to generate base-populations for obtaining lines. Semin. Cienc. Agrar. 34: 7-18. http://dx.doi.org/10.5433/1679$\underline{0359.2013 v 34 n 1 p 7}$

Pfann AZ, Faria MV, de Andrade AA, do Nascimento IR, et al. (2009). Capacidade combinatória entre híbridos simples de milho em dialelo circulante. Cienc. Rural 39: 635-641. http://dx.doi.org/10.1590/S0103-84782009000300002

Senhorinho HJC, Pinto RJB, Scapim CA, Milani KF, et al. (2015). Combining abilities and inbreeding depression in commercial maize hybrids. Semin. Cienc. Agrar. 36: 4133-4150. http://dx.doi.org/10.5433/16790359.2015v36n6Supl2p4133

Silva DJ and de Queiroz AC (2012). Análise de alimentos: métodos químicos e biológicos. 3rd edn. UFV, Viçosa.

Tilley JMA and Terry RA (1963). A two-stage technique for the in vitro digestion of forage crops. J. Br. Grassl. Soc. 18: 104-111. http://dx.doi.org/10.1111/j.1365-2494.1963.tb00335.x

Van Soest PJ, Robertson JB and Lewis BA (1991). Methods for dietary fiber, neutral detergent fiber, and nonstarch polysaccharides in relation to animal nutrition. J. Dairy Sci. 74: 3583-3597. http://dx.doi.org/10.3168/jds.S0022$\underline{0302(91) 78551-2}$ 